\title{
East Java Modeling Techniques to Improve Student Meaning of Life
}

\author{
Nur Hidayah \\ Department of Guidance and Counseling \\ State University of Malang, Indonesia \\ nur.hidayah.fip@um.ac.id
}

\author{
M. Ramli \\ Department of Guidance and Counseling \\ State University of Malang, Indonesia \\ m.ramli.fip@um.ac.id
}

\author{
Husni Hanafi \\ Student Postgraduate Program \\ State University of Malang, Indonesia \\ husni.hanafi.1601118@students.um.ac.id
}

\begin{abstract}
Indonesia as a diverse tribe country has a distinctive cultural value, including the cultures of Madura, Samin and Tengger in East Java. These cultural values form a system of meaning of life for the people of Madura, Samin and Tengger, including students with a Madurese, Samin or Tengger cultural background. Counseling with Madura culture modeling techniques can be an alternative in an effort to increase the meaning of life of students. This is due to the suitability of modeling techniques with the cultural values of Madura, Samin and Tengger which have significant others with great influence. Thus, modeling of significant others with the influence of magnitude on the cultivation of cultural values of Madura, Samin or Tengger becomes in line with efforts to increase the meaning of life of students based on the cultural value of Madura, Samin or Tengger.
\end{abstract}

Keywords: modeling, madura, samin, tengger, meaning of life

\section{INTRODUCTION}

Indonesia is one of the countries with the largest number of tribes. The latest population census data by the Central Bureau of Statistics states that there are currently 633 large ethnic groups (BPS, 2015). These large ethnic groups can become thousands of sub-tribes in Indonesia. All of these tribes are spread throughout Indonesia.

Java Island as the most populous island in Indonesia is divided into several provinces. East Java Province became a province with several tribal wealth, namely there were seven indigenous tribes of East Java and various immigrant tribes. East Java has Madurese on Madura Island, Samin in Bojonegoro, Tengger on Mount Bromo, Bawean on Bawean Island, Osing in Banyuwangi, Java Pandalungan around the north coast and Java Matraman in Ponorogo (Hidayah, 2017).

The seven tribes are indigenous tribes that live in East Java. In addition to the 7 tribes there are still sub-tribes of the tribe and tribes of immigrants such as Banjar, Batak, Bugis, Arabs and others. The Madurese, Samin and Tengger tribes as the indigenous people of East Java have their own uniqueness. The Madurese have a demographic condition that lives on a separate island from the island of Java.

The Tengger people live on Mount Bromo and declare themselves as wong gunung (Mountain People). While the Samin tribe is a tribe known for its unique resistance during the Dutch colonial era. These uniqueness helped make the strong character of the tribes in East Java.

In addition to these conditions, the uniqueness of each tribe is at their cultural value. Emically, the cultural values of each tribe will guide their way of life (Sue \& Sue, 2008). Cultural values in the tribes in East Java are still held firm and become the basis of their lives. Cultural values contribute to the identity of each tribe member of their culture through their knowledge, attitudes, beliefs, traditions and way of life (Kaul, 2012).

In addition to these conditions, the uniqueness of each tribe is at their cultural value. Emically, the cultural values of each tribe will guide their way of life (Sue \& Sue, 2008). Cultural values in the tribes in East Java are still held firm and become the basis of their lives. Cultural values contribute to the identity of each tribe member of their culture through their knowledge, attitudes, beliefs, traditions and way of life (Kaul, 2012).

Madurese have their own cultural values, one of which is bhupa', bhabhu', ghuru, rato'. This value literally means father, mother, teacher and queen. The meaning of the Madurese community of bhupa, bhabhu', ghuru, rato' is respect, obedience and priority for every parent, teacher and leader for every Madurese community (Rifa'i, 2007). This value is the basis of Madurese society in life by prioritizing parents, teachers and leaders.

While the Samin tribe also has its distinctive cultural values, namely angger-angger. The cultural values of the members in the Samin community have teachings related to the law of speech (angger-angger pangucap), the law of behavior (angger-angger pertikel), and the law of implementation (anggerangger lakunana) (Amalia, 2017). The teachings of Samin members are the teachings of the serat uri-uri pambudi in the book Jamus Kalimasodo.

The planting of Saminism of the Samin community in Bojonegoro, East Java was given by the adat leader Samin, namely Mbah Harjo Kardi. Like the Madurese and Samin, the Tengger tribe also has values that are also upheld. This value is one of the sabda 
pandhita ratu, which has the meaning of obedience to the teachings of life delivered by the leader (adat leader). In addition to the values of sabda pandhita ratu, the Tengger Tribe also has the welas asih pepitu and the prohibition of Pancasroda (Andrianto et al, 2013). These values for the Tengger people are a guide to a peaceful and prosperous life.

Madura, Samin and Tengger cultural values describe different forms of value and are unique to each culture. However, there is one same value, namely the existence of a significant other role in the lives of Madurese, Samin and Tengger people. Significant others in the culture of Madura, Samin and Tengger have a very large influence on the aspects of life of members of their society.

The condition of the importance of significant others also has an impact on how the meaning of life of the people of Madura, Samin and Tengger. Meaning of life in the sense of the meaning of life is how an individual understands his life, starting from how an individual has hope in his life and to have a reason for everything he does in maintaining a meaningful life (Frankl, 1992).

Wolf (2010) argues that meaning arises when subjective attraction meets objective attractiveness which can be interpreted that the search for individual meaning of life needs to involve each of the subjective components and objective components. Steger (2008) also states the similarity that the presence of meaning of life cannot be separated in relation to how a person views himself and the influence of culture. Every culture has an influence in the form of intersubjective truth or agreement with the community, which in turn forms the cultural meaning of life for each member to have (Hanafi et al, 2018).

Students with a Madura, Samin or Tengger cultural background certainly have different meanings of life. Meaning of life students are influenced by local culture and life experiences. The first influence of culture is the main factor influencing a person's life. Since childhood, students live in an environment full of culture, both family culture and the culture of the community where they live.

The second influence is the student's life experience that is unique. Students have routine activities to do both at home and at school. This routine provides a life experience both positive and negative experiences. Positive experience makes students satisfied with the actions taken. Negative experience can be traumatic for students who do not dare to face life failure. The ability of students to accept positive and negative experiences influences the formation of meaning of life in themselves.

The process of forming and fulfilling the meaning of life for each student will run differently. But the objectivity in the meaning of life provides space for educators in schools to help students improve their meaning of life. Counseling as one of the professional services carried out by counselors at school becomes necessary to help students improve their meaning of life.

Counseling in East Java by counselors is more familiar in the use of behavioral cognitive counseling models (Hidayah \& Ramli, 2017). Cognitive behavioral counseling model. The framework of behavioral cognitive counseling models is a form of counseling that combines principles and procedures of cognitive counseling and behavioral counseling in an effort to help counselees achieve the expected changes that are expected (Corey, 2005, 2009, 2013; Ramli, 2005). This condition makes the techniques in cognitive behavioral models can be chosen to be used in increasing the meaning of life of students with Madurese or Samin or Tengger cultural backgrounds.

Modeling technique is a technique that is deemed appropriate in an effort to help students with a cultural background in East Java (Madura, Samin or Tengger) to improve their meaning of life. This selection is based on the existence of a significant others role that is very important in every aspect of the life of the Madurese, Samin and Tengger people. Significant Others for the people of Madura, Samin and Tengger also have a role in guiding themselves to carry out life according to existing cultural values.

\section{METHODS}

The research design used in this study adapted the development research design proposed by Borg \& Gall (2003). The selection of development research design proposed by Borg \& Gall was based on the general purpose of this development research, namely the production of a product in the form of counseling modeling techniques for students' meaning of life in East Java.

The procedures for this research development are (1) preliminary study through literature and the needs of Madura, Samin, and Tengger cultural counselors, (2) product development planning, (3) the preparation and development of prototyping modeling techniques for students' meaning of life in East Java.

The instrument used in this study is the rating scale. The rating scale is intended to assess the draft of counseling modeling techniques for meaning of life of students in East Java by counseling experts and cultural experts. The data analysis technique is the percentage followed by the meaning of the results.

\section{RESULT}

The results obtained from this study are the design of modeling techniques to be applied in an effort to improve the meaning of life of students in East Java. In particular the design of modeling counseling techniques is adapted to the cultures of Madura, Samin and Tengger. The design results are presented in Table 1 for Madura culture, Table 2 for Samin culture, and Table 3 for Tengger culture.

The design of this modeling technique is based on the main values of Madura, Samin and Tengger culture. Madura cultural modeling techniques focus on the values of the teachings of bhupa', bhabhu', ghuru, rato'. Samin's cultural modeling technique focuses on the central role of Mbah Harjo Kardi in teaching Jamus Kalimasodo. The Tengger culture modeling technique focuses on the teaching values of the sabda pandhita ratu. These three foci are a manifestation of the role of significant others in the counselees of Madura. 
Table 1

Madurese Modeling Techinique

\begin{tabular}{|c|c|c|}
\hline No & $\begin{array}{l}\text { Modeling } \\
\text { Steps }\end{array}$ & Spesific Steps \\
\hline \multirow[t]{2}{*}{1} & \multirow[t]{2}{*}{ Expossure } & $\begin{array}{l}\text { Counselors and counselors observe } \\
\text { the complete behavior of Bhupa', } \\
\text { Bhabhu', Ghuru, Rato }\end{array}$ \\
\hline & & $\begin{array}{l}\text { The counselor invited the counselee } \\
\text { to detail the complex behavior of } \\
\text { Bhupa', Bhabhu', Ghuru, Rato to be } \\
\text { more detailed }\end{array}$ \\
\hline \multirow[t]{2}{*}{2} & \multirow[t]{2}{*}{ Acquisition } & $\begin{array}{l}\text { Counselors help counselees form } \\
\text { Bhupa', Bhabhu', Ghuru, Rato } \\
\text { behaviors to be chosen }\end{array}$ \\
\hline & & $\begin{array}{l}\text { Counselors and counselors } \\
\text { formulate the form, duration, power } \\
\text { of the chosen Bhupa', Bhabhu', } \\
\text { Ghuru, Rato behavior }\end{array}$ \\
\hline \multirow[t]{4}{*}{3} & \multirow[t]{4}{*}{ Acceptance } & $\begin{array}{l}\text { The counselee internalizes the value } \\
\text { of behavior in him }\end{array}$ \\
\hline & & $\begin{array}{l}\text { The counselor strengthens the } \\
\text { counselee to accept the new } \\
\text { behavior he chooses }\end{array}$ \\
\hline & & $\begin{array}{l}\text { The counselor strengthened the } \\
\text { counselee using the value of } \\
\text { Bhupa', Bhabhu', Ghuru, Rato'. }\end{array}$ \\
\hline & & $\begin{array}{l}\text { Counselors and counselees } \\
\text { formulated Bhupa', Bhabhu', } \\
\text { Ghuru, Rato behaviors that were } \\
\text { chosen according to the conditions } \\
\text { of the counselee. }\end{array}$ \\
\hline \multirow[t]{6}{*}{4} & \multirow[t]{6}{*}{$\begin{array}{l}\text { Behavior } \\
\text { Rehearsal }\end{array}$} & $\begin{array}{l}\text { Counselors and counselees } \\
\text { formulate behavioral training } \\
\text { preparation }\end{array}$ \\
\hline & & $\begin{array}{l}\text { Counselors help counselees prepare } \\
\text { exercise schedules }\end{array}$ \\
\hline & & $\begin{array}{l}\text { Counselors seek to monitor } \\
\text { counselee training (if possible) }\end{array}$ \\
\hline & & $\begin{array}{l}\text { The counselor reflects on the } \\
\text { counselee's training }\end{array}$ \\
\hline & & $\begin{array}{l}\text { The counselor asks the counselee to } \\
\text { practice independently and report } \\
\text { on his progress }\end{array}$ \\
\hline & & $\begin{array}{l}\text { Counselors provide follow-up to } \\
\text { improve counselee behavior. }\end{array}$ \\
\hline
\end{tabular}

\section{DISCUSSION}

Before you begin to format your paper, first write and save the content as a separate text file. Complete all content and organizational editing before formatting. Please note sections A-D below for more information on proofreading, spelling and grammar.

The modeling technique developed refers to the cultural values of Madura, Samin and Tengger. The cultural value of significant others in the individual becomes the main value in the cultural modeling techniques of Madura, Samin and Tengger. Thus, modeling techniques in the form of live modeling are the most appropriate and touch the cultural values of Madura, Samin and Tengger.

The behavior that is a model of Madura cultural modeling techniques is the behavior of fathers, mothers, teachers and leaders. The process of forming new behaviors through modeling will examine how counselees observe the behavior of fathers, mothers, teachers and leaders (in this case the scholars, elders and regional leaders). The fourth position of the figure who is the significant others for Madura counselees will facilitate the counselee in accepting and internalizing the behavior of the model into their own behavior.
Table 2

Samin Modeling Techinique

\begin{tabular}{|c|c|c|}
\hline No & $\begin{array}{l}\text { Modeling } \\
\text { Steps }\end{array}$ & Spesific Steps \\
\hline \multirow[t]{2}{*}{1} & \multirow[t]{2}{*}{ Expossure } & $\begin{array}{l}\text { The counselor and counselor } \\
\text { observe the whole behavior of } \\
\text { Mbah Harjo }\end{array}$ \\
\hline & & $\begin{array}{l}\text { The counselor invited the counselee } \\
\text { to detail the complex behavior of } \\
\text { Mbah Harjo to be more detailed }\end{array}$ \\
\hline \multirow[t]{2}{*}{2} & \multirow[t]{2}{*}{ Acquisition } & $\begin{array}{l}\text { Counselors help counselees } \\
\text { formulate the behavior of mbah } \\
\text { harjo to be chosen }\end{array}$ \\
\hline & & $\begin{array}{l}\text { Counselors and counselors } \\
\text { formulate the form, duration, power } \\
\text { of the behavior of the chosen mbah } \\
\text { harjo }\end{array}$ \\
\hline \multirow[t]{4}{*}{3} & \multirow[t]{4}{*}{ Acceptance } & $\begin{array}{l}\text { The counselee internalizes the value } \\
\text { of behavior in him }\end{array}$ \\
\hline & & $\begin{array}{l}\text { The counselor strengthens the } \\
\text { counselee to accept the new } \\
\text { behavior he chooses }\end{array}$ \\
\hline & & $\begin{array}{l}\text { The counselor strengthened the } \\
\text { counselee by discussing the role of } \\
\text { mbah harjo kardi as the leader of } \\
\text { the Samin tribe and the teachings of } \\
\text { Jamus Kalimasodo. }\end{array}$ \\
\hline & & $\begin{array}{l}\text { Counselors and counselees } \\
\text { formulate the chosen behavior of } \\
\text { Harjo with the needs of the } \\
\text { counselee's condition. }\end{array}$ \\
\hline \multirow[t]{6}{*}{4} & \multirow[t]{6}{*}{$\begin{array}{l}\text { Behavior } \\
\text { Rehearsal }\end{array}$} & $\begin{array}{l}\text { Counselors and counselees } \\
\text { formulate behavioral training } \\
\text { preparation }\end{array}$ \\
\hline & & $\begin{array}{l}\text { Counselors help counselees prepare } \\
\text { exercise schedules }\end{array}$ \\
\hline & & $\begin{array}{l}\text { Counselors seek to monitor } \\
\text { counselee training (if possible) }\end{array}$ \\
\hline & & $\begin{array}{l}\text { The counselor reflects on the } \\
\text { counselee's training }\end{array}$ \\
\hline & & $\begin{array}{l}\text { The counselor asks the counselee to } \\
\text { practice independently and report } \\
\text { on his progress }\end{array}$ \\
\hline & & $\begin{array}{l}\text { Counselors provide follow-up to } \\
\text { improve counselee behavior. }\end{array}$ \\
\hline
\end{tabular}

The process of accepting and internalizing model behavior also occurs in Samin's cultural modeling techniques. Mbah Harjo Kardi as the customary leader has a huge influence on the cultivation of cultural and life values for the Samin community in Bojonegoro. Mbah Harjo Kardi's great influence would be appropriate if he was chosen to be a live model for counselees with Samin culture. Mbah Harjo Kardi as the main figure in Samin culture-values cultivation will certainly have Samin cultural values that can be a model for students with Samin culture.

Tengger culture modeling techniques have significant others that differ from Madura and Samin cultures. The leaders and elders of adat are influential figures in the lives of individuals in the Tengger culture. Unlike the Samin community, the Tengger traditional leaders and elders are more than one and each village has its own. Nevertheless, the leaders and elders of the Tengger custom have a great influence on the cultivation of the cultural values and life of the Samin people. So that the customary leaders and indigenous elders of the Tengger community can certainly be a live model for students with a Tengger cultural background. 
Table 3

Tengger Modeling Techinique

\begin{tabular}{|c|c|c|}
\hline \\
\hline No & $\begin{array}{l}\text { Modeling } \\
\text { Steps }\end{array}$ & Spesific Steps \\
\hline \multirow[t]{2}{*}{1} & \multirow[t]{2}{*}{ Expossure } & $\begin{array}{l}\text { The counselor and counselor } \\
\text { observe the complete behavior of } \\
\text { ratu (traditional leader) and } \\
\text { indigenous elders. }\end{array}$ \\
\hline & & $\begin{array}{l}\text { The counselor invited the counselee } \\
\text { to detail the complex behavior of } \\
\text { ratu (traditional leader) and adat } \\
\text { elders to be more detailed }\end{array}$ \\
\hline \multirow[t]{2}{*}{2} & \multirow[t]{2}{*}{ Acquisition } & $\begin{array}{l}\text { The counselor helps the counselee } \\
\text { formulate the behavior of the queen } \\
\text { (traditional leader) and indigenous } \\
\text { elders who will be chosen }\end{array}$ \\
\hline & & $\begin{array}{l}\text { Counselors and counselors } \\
\text { formulate the form, duration, power } \\
\text { of the behavior of ratu (adat leader) } \\
\text { and the chosen adat elders }\end{array}$ \\
\hline \multirow[t]{4}{*}{3} & \multirow[t]{4}{*}{ Acceptance } & $\begin{array}{l}\text { The counselee internalizes the value } \\
\text { of behavior in him }\end{array}$ \\
\hline & & $\begin{array}{l}\text { The counselor strengthens the } \\
\text { counselee to accept the new } \\
\text { behavior he chooses }\end{array}$ \\
\hline & & $\begin{array}{l}\text { Counselors strengthen counselees } \\
\text { using penanman value sabda } \\
\text { pandhita ratu. }\end{array}$ \\
\hline & & $\begin{array}{l}\text { Counselors and counselees } \\
\text { formulate the behavior of ratu } \\
\text { (traditional leaders) and indigenous } \\
\text { elders who are selected with the } \\
\text { needs of the counselee's condition. }\end{array}$ \\
\hline \multirow[t]{6}{*}{4} & \multirow[t]{6}{*}{$\begin{array}{l}\text { Behavior } \\
\text { Rehearsal }\end{array}$} & $\begin{array}{l}\text { Counselors and counselees } \\
\text { formulate behavioral training } \\
\text { preparation }\end{array}$ \\
\hline & & $\begin{array}{l}\text { Counselors help counselees prepare } \\
\text { exercise schedules }\end{array}$ \\
\hline & & $\begin{array}{l}\text { Counselors seek to monitor } \\
\text { counselee training (if possible) }\end{array}$ \\
\hline & & $\begin{array}{l}\text { The counselor reflects on the } \\
\text { counselee's training }\end{array}$ \\
\hline & & $\begin{array}{l}\text { The counselor asks the counselee to } \\
\text { practice independently and report } \\
\text { on his progress }\end{array}$ \\
\hline & & $\begin{array}{l}\text { Counselors provide follow-up to } \\
\text { improve counselee behavior. }\end{array}$ \\
\hline
\end{tabular}

The existence of significant others in cultures in East Java is one manifestation of high social value in the people of East Java. In accordance with the concept of social learning that supports that the process of forming behavior, cognitive and personality is strongly influenced by the environment that helped shape it (Bandura, 1989). In East Java cultural modeling techniques, significant others of cultured Madurese, Samin or Tengger culture have a role in the formation of cognitive behavior, which in the long term will also shape the counselee's personality.

The role of significatn others in the lives of Madurese, Samin and Tengger people is also based on the Indonesian culture as a collectivist culture. Communities in collectivist cultures tend to have a purpose in life in the form of peace and harmony between themselves, the people around them and their environment (LeFebvre \& Franke, 2013). The purpose of the harmony of collectivist civilized society becomes the basis for the interests and environmental conditions to become more mainstream. Collectiveist cultural communities have a problem-solving direction in the form of adjustments to the environment, not organizing the environment for personal needs (Kuo, 2013). This condition is the basis for the cultural counselees of Madura, Samin and Tengger to adjust to the values in their environment through the behavior modeled by the significant others around them.

The counselee's adjustment to the prevailing cultural values in the environment also leads the counselee to the formation and fulfillment of his meaning of life. Cultural values as an objective element of the form of meaning of life in the individual will be influenced by the cultivation of values by the environment. Madura cultural modeling techniques that involve counselees significant others with its influence on Madura cultural values become in line with the goal of increasing the counselee's meaning of life based on Madura cultural values. The same condition also occurs in Samin and Tengger's cultural modeling techniques.

Increasing the meaning of life of students through East Java culture modeling techniques has a match with the development of meaning of life in the perspective of the Transactional approach. The transactional approach describes the mechanism of the individual in the development of positive life through his ability to meet the criteria of a life framework, a belief system that is appropriate to his environment (1973). In other words, individuals need to fulfill the values, goals, needs and roles in their adopted culture.

The ability of individuals to adjust their values, goals, needs, and roles in society will lead individuals to the social acceptance of their cultural communities. This social acceptance is a form of individual behavior and suitability with applicable intersubjective truths. In the end, social acceptance of the suitability of individual cultural values becomes a form of fulfilling the objectivity of its cultural meaning of life.

\section{CONCLUSION}

The results of this study provide conclusions in the form of suitability of Madura, Samin and Tengger culture modeling techniques to help increase the meaning of life of students. The suitability conditions can be obtained from the involvement of significant others in modeling the culture of Madura, Samin and Tengger. Subsequent conformity is obtained through the concept of fulfilling meaning of life which requires the involvement and acceptance of the cultural environment as an objective element of meaning of life.

The advice given on the results of this study is that there can be specific studies on the framework of meaning of life of Madura, Samin and Tengger cultures. In addition, the modeling techniques that have been developed can be refined through testing in the form of theoretical validation (expert judgment) and practical validation (effectiveness test).

\section{REFERENCES}

[1] N. Hidayah and M. Ramli, "Need of CognitiveBehavior Counseling Model Based on Local Wisdom to Improve Meaning of life of Madurese Culture Junior High School Students.," in Advances in Social Science, Education and Humanities Research, volume 128., Malang, 2017. 
[2] M. Ramli, "Terapi Perilaku Kognitif," in Pendidikan dan Konseling di Era Global, Bandung, BK UPI, 2005.

[3] M. A. Rifai, Manusia Madura: pembawaan, perilaku, etos kerja, penampilan, dan pandangan hidupnya seperti dicitrakan peribahasanya., Yogyakarta: Pilar Media, 2007.

[4] M. F. Steger, "The meaningful life in Japan and the United States: Levels and correlates of meaning in life.," Journal of Research in Personality, pp. 660-678, 2008.

[5] S. Wolf, The Meaning of life and Why It Matters, Princeton, New Jersey : Princeton University Press, 2010.

[6] M. Amalia, N. Hidayah and L. Fauzan, "Meaning of Life Siswa Sekolah Menengah Pertama dengan Latar Belakang Budaya Samin," Jurnal Kajian Bimbingan dan Konseling, vol. 2, no. 3, pp. 97 106, 2017.

[7] A. d. Adrianto, Kearifan Lokal, Yogyakarta: alai Pelestarian Nilai Budaya (BPNB) Daerah Istimewa Yogyakarta, 2013.

[8] A. Bandura, "Social cognitive theory," in Annals of child development. Vol. 6. Six theories of child development, Greenwich, JAI Press, 1989, pp. 160.

[9] W. R. Borg and M. D. Gall, Educational Research: An Introduction (7th Edition), USA: Pearson Education, Inc., 2003.

[10] G. Corey, 2013, Boston: Cengage Learning, Theory and Practice of Counseling and Psychotherapy: Ninth Edition.

[11] V. E. Frankl, Man's Search for Meaning: An Introduction to Logotherapy 4th Edition, Boston: Beacon Press, 1992.

[12] H. Hanafi, N. Hidayah and A. Mappiare, "2018," Jurnal Pendidikan: Teori, Penelitian, dan Pengembangan, vol. 3, no. 9, Adopsi Nilai Budaya Osing dalam Kerangka Objektifitas Meaning of life.

[13] V. Kaul, "Globalisation and crisis of cultural identity," Journal of Research in International Business and Management, vol. 2, no. 13, pp. 341349, 2012.

[14] B. Kuo, "Collectivism and coping: Current theories, evidence, and measurements of collective coping," International Journal of Psychology, vol. 48, no. 3, p. 374-388, 2013.

[15] BPS, "Mengulik Data Suku di Indonesia," Badan Pusat Statistik, 1811 2015. [Online]. Available: https://www.bps.go.id/news/2015/11/18/127/meng ulik-data-suku-di-indonesia.html. [Accessed 10 August 2018].

[16] J. Battista and A. R., "The Development of Meaning in Life," Psychiatry: Interpersonal and Biological Processes, vol. 36, no. 4, pp. 409-427, 1973.

[17] R. LeFebvre and V. Franke, "Culture Matters: Individualism vs. Collectivism in Conflict Decision-Making," Societies, vol. 3, p. 128-146, 2013.
[18] D. W. \&. S. D. Sue, Counseling the culturally diverse: Theory and practice (5th ed.), Hoboken, NJ, US: John Wiley \& Sons Inc., 2008. 